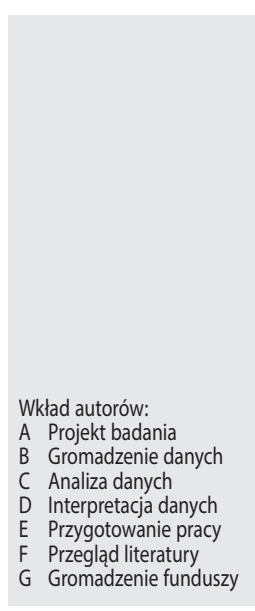

\title{
Specyficzne zaburzenie językowe - psychologiczna diagnoza sześciorga dzieci w wieku szkolnym
}

\section{Specific Language Impairment - psychological assessment of six school-age children}

\author{
Hanna B. Cygan ${ }^{\text {A-F, Martyna Bryłka }}{ }^{\text {C-F }}$ \\ Instytut Fizjologii i Patologii Słuchu, Naukowe Centrum Obrazowania Biomedycznego, \\ Warszawa/Kajetany
}

\begin{abstract}
Streszczenie
Wprowadzenie: Specyficzne zaburzenie językowe (SLI) oznacza zaburzenie rozwojowe charakteryzujące się ilościowymi i jakościowymi upośledzeniami językowymi, które odnoszą się do produkcji i/lub rozumienia języka ojczystego. W artykule przedstawiono wyniki diagnozy psychologicznej sześciorga dzieci z zaburzeniami rozwoju językowego w wieku 9-12 lat. Dokonano w niej oceny funkcjonowania dzieci w zakresie poszczególnych zdolności językowych oraz szerszego funkcjonowania poznawczego i społeczno-emocjonalnego. Opis przypadku: W badaniu wykorzystano próby kliniczne dotyczące mowy opowieściowej, fluencji słownej, rozumienia, gramatyki, słuchowej pamięci fonemów. Do oceny niewerbalnych zdolności intelektualnych zastosowano Test Matryc z baterii WAIS-IV. Oceniono również zakres występowania objawów zaburzeń emocji i zachowania u badanych dzieci, przy wykorzystaniu kwestionariusza CBCL. W wyniku diagnozy wykazano trudności w rozumieniu języka, jak i w mowie czynnej. Badane dzieci mają trudności z nazywaniem, mowa jest niepłynna, występują błędy gramatyczne. W zakresie rozumienia dzieci mają trudności ze złożoną składnią oraz z prawidłowym odbiorem kilkuelementowych poleceń, co może mieć związek ze stwierdzonym w diagnozie ograniczeniem słuchowej pamięci bezpośredniej. Stwierdzono także występowanie objawów zaburzeń emocji i zachowania, które najprawdopodobniej są konsekwencją przeżywanych trudności komunikacyjnych.

Wnioski: Wyniki badania klinicznego wskazują na potrzebę wielopoziomowego postępowania diagnostycznego i terapeutycznego uwzględniającego wsparcie rozwoju językowego, jak również oddziaływania psychologicznego wspierającego funkcjonowanie emocjonalne dzieci z SLI. Słowa kluczowe: diagnoza psychologiczna • SLI • rozwój językowy • zaburzenia rozwoju językowego • zaburzenia rozwojowe
\end{abstract}

\begin{abstract}
Background: Specific Language Impairment (SLI) is a developmental disorder characterized by quantitative and qualitative language impairments that relate to the production and/or comprehension of the native language. This paper presents results of the assessment of six children with language developmental disorders aged 9-12 years. A diagnosis of the children's functioning in terms of specific language abilities and broader cognitive and socio-emotional functioning was conducted.

Case report: The study used clinical samples on narrative speech, verbal fluency, comprehension, grammar, and auditory memory of phonemes. The Matrix Reasoning Test from the WAIS-IV battery was used to assess non-verbal intellectual abilities. The range of symptoms of emotional and behavioral disorders in the examined children was assessed using the CBCL questionnaire. The diagnosis revealed difficulties in language comprehension as well as in active speech. The examined children have difficulties with naming, verbal fluency, they commit grammatical errors. As far as comprehension is concerned, the children have difficulties with syntax and with correct understanding of a complex instructions. Comprehension problems may be related to the limited short term auditory memory that was also revealed in the diagnosis. Symptoms of emotional and behavioral disorders were also found, which are most likely a consequence of the experienced communication difficulties.

Conclusions: The results of the clinical study indicate the need for multilevel diagnostic and therapeutic management that includes support for language development, as well as psychological interventions to support the emotional functioning of children with SLI. Key words: psychological assessement $\bullet$ SLI • language development $\bullet$ developmental language disorder $\bullet$ developmental disorder
\end{abstract}

Adres autora: Hanna B. Cygan, Naukowe Centrum Obrazowania Biomedycznego, Instytut Fizjologii i Patologii Słuchu, Kajetany, 05-831 Nadarzyn, e-mail: h.cygan@ifps.org.pl 
Wykaz skrótów:

\begin{tabular}{lcc}
\hline Skrót & Rozwinięcie skrótu & $\begin{array}{c}\text { Znaczenie skrótu } \\
\text { w języku polskim }\end{array}$ \\
\hline CBCL & Child Behavior Checklist & lista kontrolna zachowania dziecka \\
\hline DLD & Developmental Language Disorders & rozwojowe zaburzenie językowe \\
\hline ICD 11 & International Classification of Diseases 11th Revision & $\begin{array}{c}\text { Międzynarodowa Statystyczna Klasyfikacja Chorób } \\
\text { i Problemów Zdrowotnych ICD-11 - jedenasta wersja }\end{array}$ \\
\hline IQ & intelligence quotient & iloraz inteligencji \\
\hline MRT & Matrix Reasoning Test & Test Matryc \\
\hline LTP & - & Logopedyczny Test Przesiewowy dla Dzieci w Wieku \\
Szkolnym
\end{tabular}

\section{Wprowadzenie}

Specyficzne zaburzenie językowe (ang. Specific Language Impairment, SLI) to zaburzenie rozwojowe charakteryzujące się ilościowym i jakościowym upośledzeniem zdolności językowych, które odnoszą się do produkcji i/ lub rozumienia języka $[1,2]$. Co ważne, deficyty językowe związane z SLI pojawiają się przy braku ogólnego opóźnienia poznawczego [2]. Problem braku porozumienia co do kryteriów i terminologii dotyczącej problemów językowych u dzieci został podjęty przez konsorcjum CATALISE. W 2017 roku konsorcjum to dokonało standaryzacji definicji, w wyniku czego przyjęto nazwe Developmental Language Disorders (DLD), która zastąpiła termin SLI. [3]. Zmiana ta została przyjęta w najnowszej klasyfikacji chorób ICD 11. Jednak ze względu na brak oficjalnego tłumaczenia oraz głębokie zakorzenienie w środowisku polskim poprzedniego terminu, $\mathrm{w}$ tym artykule będziemy się posługiwać skrótem SLI.

Diagnoza kliniczna SLI wymaga dodatkowej oceny niewerbalnego IQ oraz wykluczenia zaburzeń ze spektrum autyzmu, mutyzmu, chorób neurologicznych i upośledzenia słuchu $[4,5]$. SLI to opóźnienie w przyswajaniu języka istniejące od urodzenia, bez poprzedzającego okresu prawidłowego rozwoju i bez dającej się stwierdzić przyczyny. Uważa się, że zaburzenie ma podłoże genetyczne i dotyka nawet $7 \%$ populacji ogólnej. W omawianej grupie klinicznej występuje przewaga liczebna chłopców w stosunku do dziewczynek w proporcji ok. 3:1 [6]. Mimo że problemem deficytu rozwoju językowego badacze zajmują się od wielu lat, pojęcie SLI pojawiło się w polskiej literaturze klinicznej stosunkowo niedawno. $\mathrm{Z}$ tego powodu brak jest ustalonych w naszym kraju standardów diagnostycznych w odniesieniu do specyficznych zaburzeń językowych. W praktyce logopedycznej wykorzystywano m.in. narzędzia autorstwa Tarkowskiego do oceny trudności w aspekcie funkcjonowania językowego dzieci w wieku przedszkolnym i wczesnoszkolnym [7]. W ostatnich latach wydano test do oceny rozwoju językowego dzieci w wieku 4-9 lat - Test Rozwoju Językowego (TRJ), posiadający normy dla populacji polskiej [8] oraz Logopedyczny Test
Przesiewowy dla dzieci w wieku szkolnym (LTP), który posiada normy także dla dzieci starszych, z przedziału wiekowego 6-15 lat [9].

W niniejszym artykule zaprezentowano diagnozę psychologiczną sześciorga dzieci w wieku szkolnym, u których stwierdzono trudności dotyczące funkcjonowania językowego. W analizie omawianych przypadków zastosowano próby własne opracowane do diagnozy klinicznej. Dodatkowo w badaniach zastosowano narzędzia do oceny pozajęzykowych funkcji poznawczych oraz diagnozę funkcjonowania społecznego i emocjonalnego dzieci. Przeprowadzona diagnoza posłużyła do wnikliwej analizy cech charakterystycznych pojawiających się w rozwojowych zaburzeniach językowych. Wyróżnione zostały istotne elementy funkcjonowania językowego oraz towarzyszące im objawy zaburzeń uwagi, pamięci oraz trudności społeczno-emocjonalnych. Zaprezentowana analiza może stanowić wskazówkę dla diagnostów - logopedów i psychologów - odnośnie elementarnych objawów SLI oraz proponowanych metod diagnozy na podstawie prób klinicznych.

\section{Opis przypadków}

W przeprowadzonej analizie ocena rozwoju zdolności językowych dotyczyła sześciorga dzieci (1 dziewczynka i 5 chłopców) w wieku od 9 do 12 lat. Dzieci zgłoszone zostały na diagnozę neuropsychologiczną w roku 2011 do Pracowni Neuropsychologii Rozwojowej Instytutu „Pomnik - Centrum Zdrowia Dziecka” w Warszawie z powodu trudności szkolnych. W grupie znalazły się dzieci jednojęzyczne, uczęszczające do klas II-VI szkoły podstawowej.

Dzieci poddane zostały diagnozie uwzględniającej kryteria diagnostyczne specyficznych zaburzeń językowych $[5,6]$. U wszystkich badanych wystąpiły wybiórcze trudności dotyczące zdolności werbalnych. W każdym przypadku miał miejsce opóźniony rozwój mowy. W wywiadzie wykluczono zaburzenia mowy o podłożu psychogennym. Matki zgłaszały, że okres ciąży i połogu przebiegał bez 
zakłóceń. W badaniach medycznych wykluczono: choroby oraz uszkodzenia neurologiczne, zaburzenia słuchu, całościowe zaburzenia rozwoju.

Diagnoza funkcji intelektualnych wykazała u wszystkich dzieci z tej grupy prawidłowy poziom rozwoju pozawerbalnych funkcji poznawczych. Przeprowadzone próby kliniczne dotyczyły: zdolności wzrokowo-przestrzennych, rozumowania przyczynowo-skutkowego oraz pamięci wzrokowej. Na podstawie wywiadów z opiekunami oraz obserwacji zachowań dzieci wykluczono zaburzenia w dwustronnych interakcjach społecznych.

Ponadto u żadnego z badanych dzieci nie stwierdzono zaburzeń rozwoju artykulacyjnego. W związku z tym dalsza ocena rozwoju mowy objęła poziom systemu językowego z pominięciem sfery artykulacyjnej.

Tabela 1 przedstawia wiek i płeć badanych dzieci. Uwidoczniona jest znaczna przewaga liczebna chłopców w badanej grupie. Struktura grupy odzwierciedla obserwowaną w populacji ogólnej przewagę liczebną chłopców nad dziewczętami wśród dzieci dotkniętych zaburzeniami rozwoju językowego $[5,6]$.

\section{Zadania diagnostyczne}

Diagnoza SLI przeprowadzona została na podstawie eksperymentalnych prób klinicznych. Próby zostały tak dobrane, by uwidocznić najbardziej charakterystyczne objawy zaburzeń sprawności językowej u dzieci z SLI $[5,6]$. Zadania dotyczyły zdolności rozumienia prostych i złożonych konstrukcji zdaniowych oraz, w zakresie mowy czynnej, fluencji słownej, użycia odpowiednich form gramatycznych i konstruowania prawidłowych wypowiedzi w oparciu o materiał obrazkowy. Ostatnia z wymienionych prób pozwala na sprawdzenie zdolności nazywania oraz zdolności formułowania zdań poprawnych pod względem gramatycznym i składniowym.

Oprócz zadań odnoszących się wyłącznie do funkcjonowania językowego zastosowano próbę zdolności przetwarzania informacji werbalnej przez bezpośrednią pamięć słuchową [10]. Panowanie nad materiałem słownym, polegające na utrzymaniu go w pamięci bieżącej, jest istotnym elementem zdolności warunkujących rozumienie przekazu werbalnego. Zatem zaburzenie rozumienia przekazu werbalnego może być warunkowane także przez zakłócenie funkcji pamięciowych diagnozowanych w odniesieniu do dzieci z SLI [11-13].

W ocenach klinicznych wykorzystano także niewerbalne zadanie wymagające abstrakcyjnego rozumowania. Wprowadzono je celem sprawdzenia, czy trudności językowe wiążą się z zakłóceniami rozwoju zdolności rozwiązywania abstrakcyjnych problemów.

Dodatkowym elementem diagnozy była ocena funkcjonowania emocjonalnego dzieci z SLI. Wywiady $\mathrm{z}$ rodzicami wskazały bowiem na duże obciążenie i stres przeżywany przez dzieci w związku z doświadczanymi trudnościami. U wielu dzieci zaburzenia językowe znacznie ograniczają interakcje społeczne, powodują wycofanie i niechęć do kontaktów z rówieśnikami. Celem ujawnienia,
Tabela 1. Charakterystyka demograficzna badanej grupy (płeć: k - kobieta; m - mężczyzna; wiek: lata:miesiące)

Table 1. Demographic characteristics of the study group (gender: $\mathrm{k}$ - female; $\mathrm{m}$ - male; age: years:months)

\begin{tabular}{lcccccc}
\hline $\begin{array}{l}\text { Zmienne } \\
\text { demograficzne }\end{array}$ & JR & KL & KM & KG & JM & EK \\
\hline Płeć & $\mathrm{m}$ & $\mathrm{k}$ & $\mathrm{m}$ & $\mathrm{m}$ & $\mathrm{m}$ & $\mathrm{m}$ \\
\hline Wiek & $9: 01$ & $9: 06$ & $9: 09$ & $10: 09$ & $11: 01$ & $12: 07$ \\
\hline
\end{tabular}

czy trudności emocjonalne dzieci z SLI mają znamiona zaburzeń psychiatrycznych, wprowadzono polską adaptację [14] kwestionariusza CBCL (Child Behavior Checklist) [15] przeznaczonego dla rodziców.

\section{Próby kliniczne zastosowane do oceny zdolności językowych}

1. Mowa opowieściowa: 3 historyjki obrazkowe: dwie czteroelementowe i jedna trzyelementowa (rycina 1). Wynik zaprezentowany został w postaci analizy jakościowej i ilościowej popełnionych przez dzieci błędów językowych.

2. Test fluencji słownej: zawierający dwie kategorie: słowa rozpoczynające się na głoskę „k” oraz nazwy zwierząt. Zadaniem dzieci było wymienienie w ciągu minuty jak największej liczby słów z danej kategorii. Wynik wyrażony został liczbą wymienionych poprawnych słów $\mathrm{z}$ danej kategorii.

3. Rozumienie: plansza zawierające układ figur - kół i trójkątów w różnych kolorach. Zadanie polegało na wskazaniu na zaprezentowanej planszy figur spełniających podane przez badacza kryteria. Dotyczyły one kolorów, umiejscowienia i wzajemnych relacji figur pod względem ich położenia (nad, pod, między itp.). Próba zawiera 12 poleceń - od prostych, niosących informację z jednej kategorii, do złożonych, zawierających informacje kilkuelementowe i $\mathrm{z}$ różnych kategorii. Wynik testu został wyrażony w liczbie popełnionych błędów. Polecenia do dzieci w próbie rozumienia:

Pokaż:

- niebieski trójkąt i czerwony trójkąt;

- czerwoną figurę i koło;

- figurę, która nie jest kołem i nie jest żółta ani zielona;

- figurę, która nie jest trójkątem, ale jest niebieska lub czarna;

- czerwone koło na końcu a niebieski trójkąt na początku;

- wszystkie trójkąty a potem żółte koło;

- czarne koło i drugi kształt w trzecim rzędzie;

- trójkąt pod czarnym kołem i kształt nad czerwonym trójkątem;

- kształt, który jest pod jednym trójkątem i obok drugiego trójkąta;

- kształt między dwoma kołami i pod trójkątem;

- koło, które jest po lewej od trójkąta i pod kołem;

- drugie koło w I kolumnie i pierwsze koło w ostatniej kolumnie; 
a)

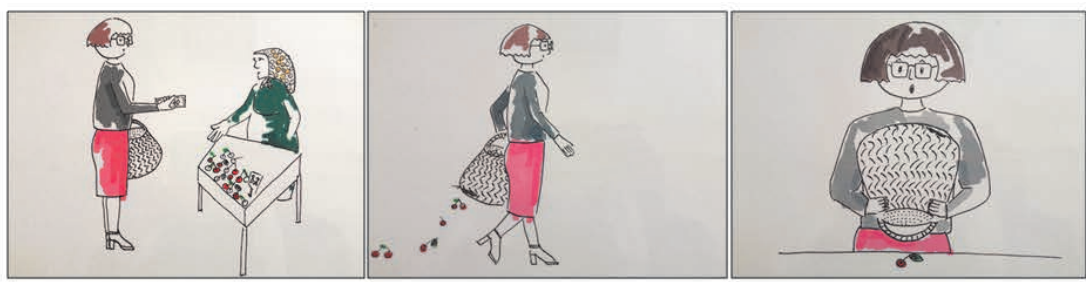

b)

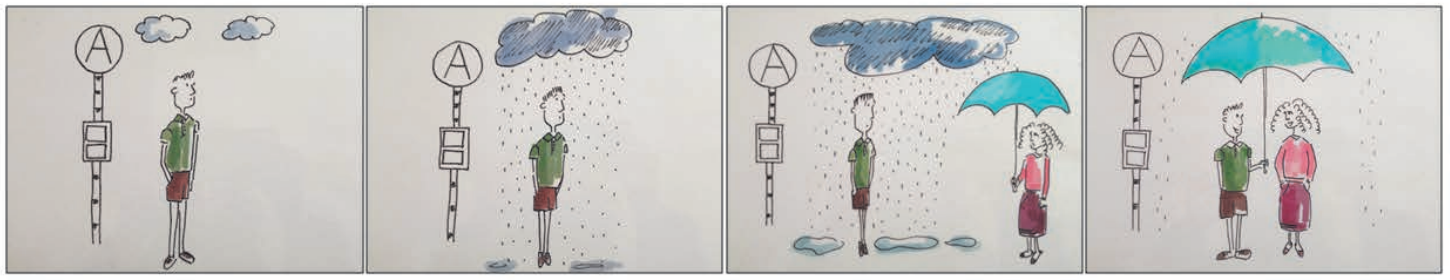

c)

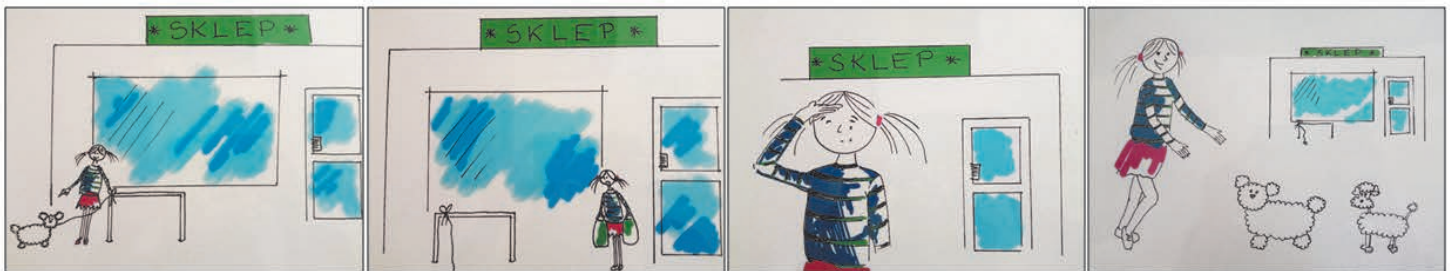

Rycina 1. Historyjki obrazkowe wykorzystane w próbach diagnostycznych Mowa opowieściowa

Figure 1. Picture stories used in diagnostic trials Narrative speech
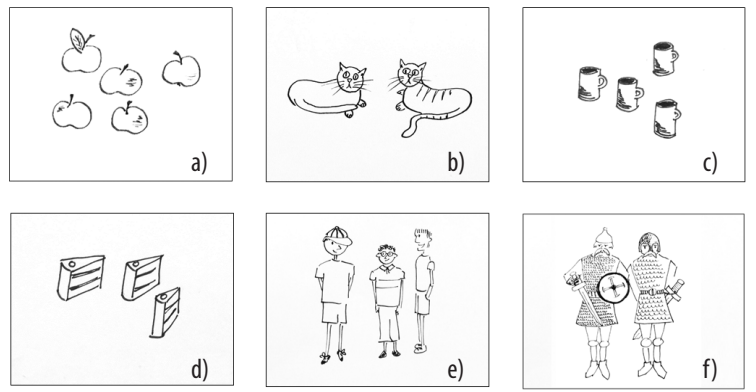

Rycina 2. Obrazki testowe zastosowane w teście Gramatyka podtest Przypadki

Figure 2. Test images used in the Grammar test - Declination subtest

4. Rozumienie konstrukcji fleksyjnych: wykonanie poleceń wyrażonych zdaniami o szyku prostym i przestawnym. Zastosowano analogiczne próby do zaproponowanych w Zeszytach Łuckiego [16]. Dziecku prezentowano trzy przedmioty - ołówek, długopis i linijkę. Zadanie polegało na wskazaniu jednego $\mathrm{z}$ tych przedmiotów przy pomocy drugiego przedmiotu. Trzy polecenia sformułowano wprost, a trzy zawierały szyk przestawny. Polecenia przekazywane były dziecku w przypadkowej kolejności, jednak zawsze jako pierwsze występowało polecenie sformułowane wprost. Wynik został wyrażony liczbą popełnionych błędów.

Przykładowe polecenia - szyk prosty:

a) Pokaż ołówek linijką.

b) Pokaż linijkę długopisem.

c) Pokaż długopis ołówkiem.

Przykładowe polecenia - szyk przestawny:

a) Pokaż ołówkiem linijkę.
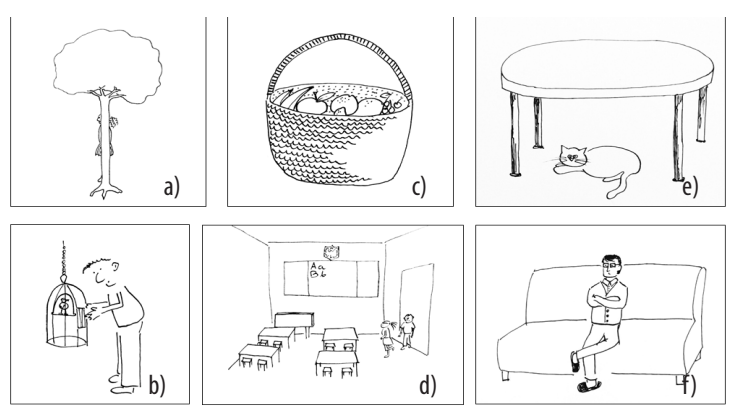

Rycina 3. Obrazki testowe zastosowane w teście Gramatyka podtest Wyrażenia przyimkowe

Figure 3. Test images used in the Grammar test - Prepositional phrases subtest

b) Pokaż linijką długopis.

c) Pokaż długopisem ołówek.

5. Gramatyka: zadanie zawierało dwie próby - kończenie sześciu zdań odpowiednią formą wyrażenia przyimkowego oraz kończenie sześciu zdań odpowiednią formą przypadka związku wyrazowego rzeczownika z liczebnikiem. Dzieciom prezentowano obrazki i odczytywano początki zdań. Ich zadaniem było dokończenie zdania nazwą desygnatu przedstawionego na obrazku w odpowiedniej formie gramatycznej. Wynik wyrażony został w liczbie błędów popełnionych w każdej z prób. Zdania bodźcowe zastosowane w teście Gramatyka.

Przypadki (rycina 2):

a) Na półce sklepowej zostało tylko ......... .

b) Pani Jadzia mieszka $\mathrm{w}$ dużym domu $\mathrm{z}$..........

c) Mama rozlała ciepłą herbatę po równo do .... 
d) Wszyscy chcieli zjeść tort urodzinowy, ale zabrakło ..........

e) Michał kupił czekoladę, zjadł pół, a resztę oddał swoim .......... .

f) Nowa powieść przygodowa opowiada historię o .......... .

Wyrażenia przyimkowe (rycina 3):

a) Ola schowała się .......... .

b) Janek wyjmuje kanarka ......... .

c) Owoce leżą ..........

d) Dzieci po przerwie wróciły ..........

e) Gruby kot leży .........

f) Tata usiadł wygodnie ..........

6. Krótkotrwała pamięć słuchowa: do badania zastosowano próby pochodzące z Zeszytów Łuckiego [16] - powtarzanie zestawów jednosylabowych słów, sylab oraz liczb. Serie zawierają kolejno 2, 3 i 4 elementy. Wynik wyrażony jest liczbą błędów popełnionych w teście.

7. Test matryc pochodzący z WAIS- IV (Wechsler Adult Intelligence Scale - Fourth Edition) [17] - amerykańskiej wersji Skali Inteligencji Wechslera, nieposiadający norm dla populacji polskiej. Wynik został wyrażony liczbą poprawnie wykonanych pozycji testu.

8. Wypełniany przez rodziców kwestionariusz CBCL dotyczący objawów zaburzeń emocjonalnych oraz zaburzeń zachowania obserwowanych u dzieci. Pozwala na stwierdzenie objawów z ośmiu kategorii: Wycofanie, Skargi somatyczne, Lęk i depresja, Problemy społeczne, Zaburzenia myślenia, Zaburzenia uwagi, Zachowania niedostosowane, Zachowania agresywne.

\section{Przebieg badania}

Badanie miało charakter indywidualny i trwało około 40 minut. Każde z dzieci wykonywało zadania diagnostyczne w obecności psychologa kierującego badaniem. Pierwszą próbą był test matryc z WAIS-IV. Kolejność wykonania zadań werbalnych była przypadkowa. Wypowiedzi dzieci w zadaniu dotyczącym mowy opowieściowej zostały nagrane na dyktafon. W czasie trwania diagnozy dziecka rodzice proszeni byli o wypełnienie kwestionariusza CBCL.

\section{Wyniki}

\section{Mowa opowieściowa - zapis wypowiedzi dzieci}

Jedno z badanych dzieci nie podjęło próby opowiedzenia historyjek. $Z$ tego powodu analiza mowy opowieściowej uwzględnia wypowiedzi pięciorga z sześciorga badanych dzieci.

K.G.

1. „Mama poszła kupić coś, nie wiem co to. Kupiła. Idzie sobie, patrzy, coś pada, a później patrzy, nic nie ma, tylko jedną ma”.

2. „Chłopak czeka na przystanku. Patrzy, deszcz pada. Idzie pani i pyta: - Co tu pan robi? - Czekam na autobus. - Chce pan parasol? - Chcę. Dziękuję".
3. „Dziewczynka idzie do sklepu z psem. Zawiązuje psa. Kupuje coś. Później wychodzi, patrzy, gdzie pies? I mówi: - Trzeba poszukać tego psa. Znalazłem. Idziemy do domu".

J.R.

1. „Na początku pani kupiła maliny, później je rozsypały, bo była dziura. Później pani zdziwiła się, że jest tylko jedna wiśnia”.

2. „Najpierw nie było tego, nie było deszczu. Później już był deszcz. Później pan był smutny i... i... pani go pana zakryła”.

3. „Bank, nie sklep. Później... Najpierw dziewczynka chciała ten... Najpierw dziewczynka potrzebowała psa i ją zaczepiła. Później dziewczynka nie widziała psa. I później widziała jakiegoś psa i i widziała dwóch psów. To jest jego, a to nie jego".

J.M.

1. „Pani kupuje jagody, ta pani sprzedaje po osiem złotych, a pani dała 10 złotych. Pani idzie do domu i jagody spadają z koszyka. Jak wróciła do domu, był tylko jeden”.

3. „Zawiązała tutaj pieska i poszedł do sklepu. Kiedy już zrobiła zakupy, pieska nie było i strasznie płakała i potem ona znalazła swojego psa”.

K.M.

1. „Pani zapłaciła za... nie wiem, jak to się nazywa... i potem pani poszła do domu, i pani zobaczyła, że ma jedną, a a pamiętała, że miała wszystkie, a ma jedną".

2. „Najpierw czekał i nie padało. Potem panu padało i potem dalej pada, i potem z panią byli i się całowali. Pocałowała go, bo był bardzo fajny. (Gdzie stali?) Na sygnalizacji, albo to mógł być autobus".

3. „A to bajeczka. Dziewczynka zawiązała psa. Weszła do sklepu. Potem zobaczyła, że nie ma psa. Potem dziewczynka płakała, że zgubiła psa. A potem dziewczynka znalazła swojego psiaka. (Co mógł robić?) Bawić się z tą szczeniaczką".

F.K.

1. „Pani kupuje czereśni. Pani idzie do domu i się wysypały, no i została jedna”.

2. „Chłopiec czeka na autobus. Nagle zaczął padać deszcz. Tu pani przychodzi do chłopca i chłopiec trzyma parasol".

3. „Dziewczynka przywiązuje psa. Tu pies jej uciekł. Tu dziewczynka szuka psa. I dwa znalazła”.

\section{Zestawienie trudności pojawiających się w mowie opowieściowej badanych dzieci}

Podsumowując analizę wypowiedzi badanych dzieci, wyraźnie widać cechy wspólne popełnianych przez nie błędów (tabela 2). U większości badanych wystąpiła trudność z nazwaniem owocu (wiśni), który znalazł się na jednym z obrazków. Dwoje dzieci nie znalazło określenia dla owo$\mathrm{cu}$, natomiast pozostali użyli niewłaściwej nazwy (przy czym dwójka ostatecznie prawidłowo nazwała owoc). Niepodanie nazwy lub podanie błędnej może wynikać 
z niewiedzy bądź z trudności z sytuacyjną aktualizacją tej nazwy. W wielu wypadkach, mimo znajomości słów, dzieci z SLI mają trudność z jej wydobyciem. Nie ma w nich gotowości do użycia wyrazu w sytuacji wypowiedzi. Trudność potęgowana jest przez stresującą sytuację, jaką może być konieczność wykazania się przed osobą przeprowadzającą test (np. psychologiem czy logopedą) [18].

Drugim rodzajem błędów, które wystąpiły u wszystkich badanych dzieci, były błędy morfologiczne dotyczące użycia form gramatycznych odmiennych części mowy. Przeważały błędy w użyciu form czasownika. Trójka dzieci zastosowała istniejącą, ale nieadekwatną formę rodzaju czasownika. Jedno dziecko (K.M.) posłużyło się nieprawidłową formą czasownika, drugie (F.K.) popełniło błąd dotyczący niewłaściwej formy przypadka rzeczownika.

Ponadto dwoje dzieci miało trudności z płynnością wypowiedzi. Wystąpiły zaburzenia w konstruowaniu wypowiedzi przejawiające się przerwami, poszukiwaniem słowa i jego właściwej formy gramatycznej bądź formy składniowej zdania.

Wśród specyficznych cech wypowiedzi w przypadku K.G. odnotowano wprowadzenie narracji do opisu historyjki. Dziecko zaczęło wchodzić w role bohaterów opowiadań i prezentować sytuację poprzez ich wypowiedzi. Taka konstrukcja pozwala na rezygnację z mowy zależnej, uproszczenie konstruowanych zdań do zdań pojedynczych oraz użycie form pierwszej osoby (prawdopodobnie jest to forma najlepiej utrwalona przez dzieci, ponieważ jest najczęściej stosowana w codziennej komunikacji).

Wypowiedź najstarszego dziecka (E.K.) była bardzo krótka i przekazywała treść historyjki w bardzo ograniczonym zakresie.

\section{Rozumienie - szyk przestawny}

Wszystkie z badanych dzieci miały trudności z rozumieniem złożonej składni zawartej w szyku przestawnym zdania (tabela 3). W interpretacji treści polecenia dzieci nie uwzględniały końcówek fleksyjnych, a jedynie kolejność wystąpienia słów w zdaniu. Zaobserwowana prawidłowość ma znaczący wpływ na błędne rozumienie treści wyrażanych złożonymi zdaniami, w których sens przekazywany jest za pośrednictwem morfologii.

\section{Rozumienie złożonych poleceń}

Żadne z przebadanych dzieci nie poradziło sobie ze zrozumieniem wszystkich poleceń, będących przedmiotem próby rozumienia. Wynik ten świadczy o trudnościach ze zrozumieniem kilkuelementowych poleceń, wyrażających relacje położenia oraz różnice $\mathrm{w}$ kolorze i kształcie między obiektami (tabela 4).

\section{Bezpośrednia pamięć słuchowa}

Wyniki zaprezentowane w tabeli 5 wskazują, że podczas powtarzania wraz ze wzrostem liczby elementów werbalnych rosła liczba popełnianych błędów. Rezultat świadczy o obniżonej pojemności bezpośredniej pamięci słuchowej. Znacznie więcej błędów wystąpiło gdy dzieci miały za zadanie powtarzanie pojedynczych sylab bez znaczenia, niż w przypadku gdy powtarzały słowa jednosylabowe. Najprawdopodobniej zapamiętanie słów znaczących jest łatwiejsze dzięki dodatkowej informacji, którą jest nazwa desygnatu. W tym wypadku możliwe jest uruchomienie pamięci wzrokowej - wyobrażenie sobie desygnatu - bądź odwołanie do bardziej utrwalonych wzorców werbalnych. W zapamiętanie ciągu pojedynczych sylab bez znaczenia zaangażowana jest słuchowa pamięć fonemów.

\section{Fluencja}

W badaniu fluencji słownej zastosowano dwie kategorie: rzeczowniki rozpoczynające się na głoskę „k” oraz nazwy zwierząt (tabela 6). Wszystkie badane dzieci wymieniły mniej wyrazów z pierwszej kategorii niż z drugiej. U jednego dziecka różnica ta wyniosła jedynie 1 wyraz, a u pozostałych dzieci było o około połowę mniej słów rozpoczynających się na głoskę „k” niż nazw zwierząt. Wydaje się zatem, że zawężenie kategorii do konkretnej grupy semantycznej znacznie ułatwia generowanie słów. Trudność z odnajdywaniem wyrazów rozpoczynających się na daną literę może być związana $\mathrm{z}$ obniżonym poziomem zdolności analizy głoskowej wyrazów.

\section{Gramatyka}

Jedynie najstarszy badany (E.K.) nie popełnił żadnego błędu w próbach odwołujących się do znajomości zasad gramatyki (tabela 7). Ogółem dzieci popełniały podobną liczbę błędów w formach wyrażeń przyimkowych i w formach przypadka związku liczebnika z rzeczownikiem. Większość dzieci udzieliła błędnych odpowiedzi w co najmniej połowie prób z każdej kategorii.

\section{Test matryc WAIS-IV}

W przeprowadzonym teście matryc $\mathrm{z}$ baterii WAIS-IV czworo dzieci uzyskało wyniki wysokie - od 19 do 23 punktów na 26 możliwych (tabela 8). Natomiast dwoje pozostałych dzieci otrzymało wyniki bardzo niskie - na poziomie 7 i 8 punktów. Wyniki wysokie świadczą o wysoko rozwiniętej zdolności logicznego rozumowania przez analogię i rozwiązywania abstrakcyjnych problemów. Próba opiera się na materiale obrazkowym i angażuje zdolności o charakterze niewerbalnym.

\section{Objawy psychiatryczne w zachowaniu (CBCL)}

W tabeli 9 wartości oznaczone gwiazdką wskazują na istotny poziom obserwowanych objawów $\mathrm{z}$ danego obszaru zaburzeń zachowania i emocji. Dzieci, które otrzymały wyniki istotne, są zaliczane do grupy klinicznej prezentującej dane zaburzenia. U czworga $\mathrm{z}$ nich stwierdzono występowanie problemów społecznych, u jednego - zaburzeń uwagi, natomiast jedno dziecko prezentuje znacząco podwyższony poziom zachowań agresywnych. Najstarsze dziecko $\mathrm{z}$ badanej grupy (E.K.) prezentuje zaburzenia $\mathrm{z}$ trzech kategorii psychiatrycznych.

Troje dzieci, według relacji rodziców, nie prezentuje wyraźnych zaburzeń. Warto jednak zauważyć, że u wszystkich zaobserwowano pewne objawy wskazujące na odstępstwo od normy rozwojowej. Wszyscy badani uzyskali 
Tabela 2. Wykaz błędów popełnianych przez badane dzieci w wypowiedziach opisujących historyjki obrazkowe

Table 2. Specific mistakes made by the tested children in statements describing picture stories

\begin{tabular}{|c|c|c|c|c|c|}
\hline Rodzaj błędu & JR & KM & KG & JM & FK \\
\hline $\begin{array}{l}\text { Błędy } \\
\text { gramatyczne }\end{array}$ & 4 błędy rodzaju & $\begin{array}{c}1 \text { błąd formy czasu } \\
\text { czasownika }\end{array}$ & $\begin{array}{l}1 \text { błąd rodzaju } \\
\text { czasownika }\end{array}$ & $\begin{array}{l}3 \text { błędy rodzaju } \\
\text { czasownika }\end{array}$ & $\begin{array}{c}1 \text { błąd przypadka } \\
\text { rzeczownika }\end{array}$ \\
\hline Błędy nazywania & $\begin{array}{c}\text { niewłaściwa nazwa } \\
\text { owocu }\end{array}$ & $\begin{array}{l}\text { owoc wiśni } \\
\text { nie nazwany }\end{array}$ & $\begin{array}{l}\text { owoc wiśni } \\
\text { nie nazwany }\end{array}$ & $\begin{array}{c}\text { niewłaściwa nazwa } \\
\text { owocu }\end{array}$ & \\
\hline Płynność & $\begin{array}{l}\text { brak płynności } \\
\text { wypowiedzi }\end{array}$ & $\begin{array}{l}\text { mała płynność } \\
\text { wypowiedzi }\end{array}$ & & & \\
\hline $\begin{array}{l}\text { Mowa } \\
\text { opowieściowa }\end{array}$ & & & $\begin{array}{c}\text { wprowadzenie } \\
\text { narracji }\end{array}$ & & $\begin{array}{l}\text { bardzo krótka } \\
\text { wypowiedź }\end{array}$ \\
\hline Neologizmy & & obecne & & & \\
\hline Składnia & & & & & błędy składniowe \\
\hline
\end{tabular}

Tabela 3. Liczba błędów popełnionych w trzech próbach rozumienia złożonej składni

Table 3. Number of errors made in three trials of understanding complex syntax

\begin{tabular}{lcccccc}
\hline Zadanie & JR & KL & KM & KG & JM & EK \\
\hline Liczba błędów - zdanie wprost & 0 & 0 & 0 & 0 & 0 & 0 \\
\hline Liczba błędów - szyk przestawny & 1 & 2 & 3 & 3 & 3 & 1 \\
\hline
\end{tabular}

Tabela 4. Liczba błędów popełnionych w dwunastu próbach rozumienia

Table 4. Number of errors made in twelve comprehension trials

\begin{tabular}{lcccccc}
\hline Zadanie & JR & KL & KM & KG & JM & EK \\
\hline Liczba błędów - rozumienie & 7 & 4 & 9 & 9 & 5 & 3 \\
\hline
\end{tabular}

Tabela 5. Liczba błędnie odtworzonych cyfr, sylab i słów w poszczególnych próbach pamięci bezpośredniej

Table 5. Number of incorrectly reproduced numbers, syllables and words in short-term memory trials

\begin{tabular}{|c|c|c|c|c|c|c|}
\hline Zadanie & JR & KL & KM & KG & JM & EK \\
\hline $\begin{array}{l}\text { Liczba błędów } \\
\text { - powtarzanie cyfr }\end{array}$ & 2 & 0 & 0 & 5 & 0 & 0 \\
\hline $\begin{array}{l}\text { Liczba błędów } \\
\text { - powtarzanie } 2 \text { sylab }\end{array}$ & 0 & 0 & 0 & 0 & 0 & 0 \\
\hline $\begin{array}{l}\text { Liczba błędów } \\
\text { - powtarzanie } 3 \text { sylab }\end{array}$ & 5 & 3 & 10 & 8 & 9 & 1 \\
\hline $\begin{array}{l}\text { Liczba błędów } \\
\text { - powtarzanie } 4 \text { sylab }\end{array}$ & 9 & 10 & 11 & 8 & 8 & 10 \\
\hline $\begin{array}{l}\text { Liczba błędów } \\
\text { - powtarzanie } 2 \text { słów }\end{array}$ & 0 & 0 & 0 & 0 & 0 & 0 \\
\hline $\begin{array}{l}\text { Liczba błędów } \\
\text { - powtarzanie } 3 \text { słów }\end{array}$ & 1 & 2 & 2 & 4 & 3 & 0 \\
\hline $\begin{array}{l}\text { Liczba błędów } \\
\text { - powtarzanie } 4 \text { słów }\end{array}$ & 7 & 7 & 8 & 13 & 10 & 4 \\
\hline
\end{tabular}

Tabela 6. Liczba wygenerowanych przez dzieci słów z poszczególnych kategorii

Table 6. Number of words generated by children from different categories

\begin{tabular}{ccccccc}
\hline Zadanie & JR & KL & KM & KG & JM & EK \\
\hline Głoska K & 9 & 11 & 7 & 7 & 9 & 14 \\
\hline Kategoria zwierzęta & 17 & 19 & 16 & 8 & 21 & 24 \\
\hline
\end{tabular}


Tabela 7. Liczba błędów popełnionych w sześciu próbach z zakresu wyrażeń przyimkowych oraz w sześciu próbach z zakresu przypadka liczebnika i rzeczownika

Table 7. The number of errors made in the six prepositional phrase trials and in the six numeral and noun case trials

\begin{tabular}{ccccccc}
\hline Zadanie & JR & KL & KM & KG & JM \\
\hline Wyrażenia przyimkowe & 3 & 3 & 3 & 4 & 3 \\
\hline Przypadek liczebnika & 4 & 3 & 4 & 2 & 5 \\
\hline
\end{tabular}

Tabela 8. Liczba poprawnie wykonanych prób w teście matryc WAIS-IV Table 8. Number of successful trials in the WAIS-IV Matrix Reasoning Test

\begin{tabular}{ccccccc}
\hline & JR & KL & KM & KG & JM \\
\hline Test Matryc & 7 & 20 & 20 & 8 & 20 \\
\hline
\end{tabular}

Tabela 9. Objawy psychiatryczne w zachowaniu (CBCL) - znormalizowane wyniki na skali tenowej Table 9. Psychiatric Behavioral Symptoms (CBCL) - scores normalized on a ten scale

\begin{tabular}{|c|c|c|c|c|c|c|}
\hline Objaw & JR & $\mathbf{K L}$ & $\mathbf{K M}$ & KG & JM & EK \\
\hline Wycofanie & 63 & 51 & 63 & 61 & 55 & 66 \\
\hline Skargi somatyczne & 56 & 52 & 50 & 65 & 50 & 55 \\
\hline Lęk i depresja & 64 & 64 & 64 & 59 & 64 & $72 *$ \\
\hline Problemy społeczne & 65 & 65 & $73 *$ & 63 & 65 & 68 \\
\hline Zaburzenia myślenia & 69 & 57 & 57 & 67 & 57 & 65 \\
\hline Zaburzenia uwagi & 69 & 63 & 69 & $74 *$ & 69 & $70 *$ \\
\hline Zachowania niedostosowane & 59 & 54 & 50 & 59 & 54 & 59 \\
\hline Zachowania agresywne & 58 & 61 & 57 & 63 & 51 & $81 *$ \\
\hline
\end{tabular}

*Wartości oznaczone gwiazdką wskazują na klinicznie istotny poziom objawów z danego obszaru zaburzeń zachowania i emocji.

średnio najwyższe wyniki w zakresie zaburzeń uwagi oraz problemów społecznych. W tych dwóch kategoriach znalazło się po dwoje dzieci o wynikach wskazujących na występowanie zaburzeń, a wszyscy inni mieli wyniki podwyższone - na granicy normy.

Podwyższone wyniki w zakresie Zaburzeń uwagi są spójne z wcześniejszymi obserwacjami badawczymi [19-21]. Efekt zaburzeń uwagi można tłumaczyć prezentowanymi przez dzieci z SLI trudnościami w rozumieniu przekazu werbalnego. Język mówiony jest zwykle głównym regulatorem zachowań dzieci i sposobem na przywoływanie ich uwagi. W sytuacji gdy istnieje zakłócenie odbioru przekazu werbalnego, nie spełnia on swojej funkcji. Dzieci z zaburzeniami rozumienia często odwracają uwagę od kierowanych do nich poleceń, ponieważ nie mają dostępu do pełnej informacji zawartej w słowach i zdaniach. Ten sposób zdobywania informacji jest dla nich nieefektywny.

Występowanie problemów społecznych jest również zgodne z wcześniejszymi doniesieniami z badań [22]. Wystąpienie zaburzeń interakcji społecznych jest częstsze u dzieci z SLI - ze względu na ich problemy w komunikacji - w porównaniu $z$ dziećmi bez SLI [23-25]. Stanowi to poważną barierę $\mathrm{w}$ nawiązywaniu pozytywnych relacji, co może skutkować obniżeniem poczucia własnej wartości i wycofywaniem się z kontaktów. Gdy dzieci idą do przedszkola, czyli około trzeciego roku życia, opóźniony rozwój mowy powoduje, że dzieci z SLI nie są $\mathrm{w}$ stanie wchodzić $\mathrm{w}$ pełne relacje $\mathrm{z}$ rówieśnikami. Częste porażki na wczesnym etapie rozwoju nie sprzyjają późniejszemu dążeniu do poszerzania relacji społecznych.

\section{Dyskusja}

Przeprowadzone diagnozy wykazały istnienie pewnych prawidłowości wśród badanych dzieci z SLI. U wszystkich wystąpiły trudności zarówno w rozumieniu, jak i w mowie czynnej. Dzieci miały problemy z doborem słów i nazywaniem obiektów, ich wypowiedzi były uproszczone, a mowa często niepłynna. Szczególnie dużo błędów dotyczyło form gramatycznych czasownika, a także przypadka rzeczownika. U większości diagnozowanych dzieci była obniżona fluencja słowna. Dzieci w zakresie rozumienia miały trudności z prawidłowym przetwarzaniem złożonej składni oraz kilkuelementowych poleceń zawierających odniesienie do cech obiektów i relacji przestrzennych. Złe rozumienie wieloelementowych poleceń jest najprawdopodobniej związane $\mathrm{z}$ ograniczeniem bezpośredniej pamięci słuchowej. Potwierdziły to wyniki przeprowadzonych diagnoz - dzieci z SLI mają trudności $\mathrm{z}$ bezpośrednim odtwarzaniem materiału werbalnego zawierającego powyżej 2-3 elementów. 
Na podstawie badania kwestionariuszowego stwierdzono także występowanie negatywnych skutków zaburzeń językowych w obszarach zdolności społecznych oraz kondycji emocjonalnej dzieci z SLI. Wspólną cechą badanych dzieci okazały się także zaburzenia uwagi, obserwowane przez rodziców. Wszystkie te czynniki wskazują na potrzebę szerokiego postępowania terapeutycznego wobec dzieci ze specyficznymi zaburzeniami rozwoju językowego. Pogłębione badania pozwolą na opracowanie metod terapii służących poprawie ich funkcjonowania.

Bardzo istotne wydaje się uwzględnienie potrzeb dzieci z SLI w zakresie dostosowania warunków edukacji szkolnej. Są to dzieci o typowych możliwościach intelektualnych, które mimo to doświadczają dużych niepowodzeń ze względu na trudności w posługiwaniu się językiem, będącym głównym pośrednikiem w przekazywaniu wiedzy. Tym samym dzieci z SLI mają ograniczony dostęp do wiedzy i mniejsze możliwości rozwoju. W celu opracowania skutecznych metod postępowania terapeutycznego należy odróżnić zaburzenia rozwojowe występujące $\mathrm{w}$ przypadku SLI od zaburzeń nabytych w wyniku uszkodzenia układu nerwowego (nawet w okresie okołoporodowym). Zaburzenie rozwojowe świadczy o konstytucjonalnych cechach osobniczych, natomiast w przypadku uszkodzenia zostały utracone pewne możliwości, do których potencjalnego rozwoju organizm był przygotowany. Zatem terapia mowy dzieci z SLI powinna brać pod uwagę brak naturalnej możliwości przyswojenia pewnych umiejętności związanych z posługiwaniem się językiem i odwoływać się do metod kompensacyjnych umożliwiających poznanie zasad językowych [2]. Jednocześnie rozwój intelektualny powinien być wspierany za pomocą metod niewerbalnych, umożliwiających poznawanie świata w sposób zrozumiały dla dzieci ze specyficznymi zaburzeniami językowymi.
Należy zaznaczyć, że ograniczeniem zaprezentowanych tu badań jest niewielka grupa badana. W celu pogłębienia oceny zmienności objawów zaburzeń SLI badanie zastosowanymi metodami powinno objąć większe grupy dzieci z różnych grup wiekowych i odnieść wyniki dzieci z zaburzeniami językowymi do normatywnej grupy kontrolnej. Istotne będzie także porównanie objawów SLI oraz ich zmienności w czasie do objawów obserwowanych w przypadku nietypowego rozwoju językowego o charakterze odmiennym od SLI, np. wśród dzieci z opóźnionym rozwojem mowy (ORM).

Przyszłe badania powinny skupić się na poszukiwaniu neurorozwojowych mechanizmów powstawania zaburzenia rozwoju językowego. Wśród obiecujących kierunków badań nad mechanizmami tego zaburzenia wymienić można badania weryfikujące hipotezę deficytu uczenia proceduralnego (Procedural Deficit Hypothesis, PDH) [26]. Uczenie proceduralne dotyczy zdolności do wychwytywania i zapamiętywania prawidłowości wśród zmieniających się elementów otoczenia. Odbywa się w oparciu o prawdopodobieństwo występowania tych elementów i ma charakter proceduralny, tj. odbywa się bez udziału świadomego zapamiętywania. Uważa się, że w ten sposób nabywany jest język przez dzieci we wczesnym okresie rozwojowym, a zaburzenie zdolności uczenia proceduralnego może być przyczyną zakłóceń nabywania zdolności językowych obserwowanych w SLI. Potwierdzenie hipotezy PDH nie tylko pozwoliłoby na wcześniejsze interwencje ukierunkowane na pierwotne w stosunku do SLI zaburzenia zdolności uczenia proceduralnego, lecz także umożliwiłoby lepsze dostosowanie programów terapeutycznych do potrzeb dzieci z SLI i skuteczniejsze wsparcie ich rozwoju.

\section{Piśmiennictwo}

1. Pietraszko A, Domeracka-Kołodziej A, Szkiełkowska A, Krasnodębska P. Specyficzne zaburzenia mowy i języka. Nowa Audiofonologia, 2018; 7(4): 19-25.

2. Czaplewska E, Kochańska M, Maryniak A, Haman E, Smoczyńska M. SLI - specyficzne zaburzenia językowe. IBE, 2014.

3. Bishop DVM, Snowling MJ, Thompson PA, Greenhalgh T. Phase 2 of CATALISE: a multinational and multidisciplinary Delphi consensus study of problems with language development: Terminology. J Child Psychol Psychiatry, 2017; 58(10): 1068-80.

4. Jaklewicz H. Specyficzne zaburzenia rozwoju mowy i języka, w: Psychiatria dzieci i młodzieży. Namysłowska I. (red.). Warszawa: PZWL; 2004.

5. Leonard L.B. Children with specific language impairment. Cambridge (MA): MIT Press, 2014.

6. Leonard L.B. SLI - specyficzne zaburzenie rozwoju językowego. Sopot: Gdańskie Wydawnictwo Psychologiczne; 2006.

7. Tarkowski Z. Test sprawności językowej. Lublin: Wydawnictwo Polskiej Fundacji Zaburzeń Mowy; 1992.

8. Smoczyńska M, Haman E, Maryniak A, Czaplewska E, Krajewski G, Banasik N i wsp. TRJ - Test rozwoju językowego. Warszawa: Instytut Badań Edukacyjnych; 2015.

9. Grabias Z, Kurkowski M, Woźniak T. Logopedyczny test przesiewowy dla dzieci w wieku szkolnym. Lublin: Wydawnictwo: UMCS; 2002.
10. Casalini C, Brizzolara D, Chilosi A, Cipriani P, Marcolini S, Pecini C i wsp. Non-Word Repetition in Children with Specific Language Impairment: A Deficit in Phonological Working Memory or in Long-Term Verbal Knowledge? Cortex, 2007; 43: 769-76.

11. Conti-Ramsden G, Durkin K. Phonological short-term memory, language and literacy: developmental relationships in early adolescence in young people with SLI. J Child Psychol Psychiatry, 2007; 48(2): 147-56.

12. Lum JA, Conti-Ramsden G, Page D, Ullman MT. Working, declarative and procedural memory in specific language impairment. Cortex, 2012; 48(9): 1138-54.

13. Lum JA, Conti-Ramsden G, Morgan AT, Ullman MT. Procedural learning deficits in specific language impairment (SLI): A meta-analysis of serial reaction time task performance. Cortex, 2014; 51: 1-10.

14. Achenbach TM, Edelbrock C. Child behavior checklist. Burlington (Vt), 1991; 7: 371-92.

15. Wolańczyk T. Zaburzenia emocjonalne i behawioralne u dzieci i młodzieży szkolnej w Polsce. Warszawa: Akademia Medyczna; 2002.

16. Łucki W. Zestaw prób do badania procesów poznawczych u pacjentów z uszkodzeniami mózgu. Warszawa: PTP; 1995.

17. Wechsler D, Coalson DL, Raiford SE. WAIS-IV technical and interpretive manual. San Antonio (TX): Pearson; 2008. 
18. Brennen T, Vikan A, Dybdahl R. Are tip-of-the-tongue states universal? Evidence from the speakers of an unwritten language. Memory, 2007; 15: 167-76.

19. McGrath LM, Hutaff-Lee C, Scott A, Boada R, Shriberg LD, Pennington BF. Children with Comorbid Speech Sound Disorder and Specific Language Impairment are at Increased Risk for Attention-Deficit/Hyperactivity Disorder. J Abnorm Child Psychol, 2008; 36: 151-63.

20. Finneran DA, Francis AL, Leonard LB. Sustained attention in children with Specific Language Impairment (SLI). J Speech Lang Hear Res, 2009; 52: 915-29.

21. Stevens C, Sanders L, Neville H. Neurophysiological evidence for selective auditory attention deficits in children with specific language impairment. Brain Res, 2006; 1111: 143-52.
22. Beitchman J, Brownlie E. Language development and its impact on children's psychosocial and emotional development. Encyclopedia on early childhood development, 2005; 1-7.

23. St Clair MC, Pickles A, Durkin K, Conti-Ramsden G. A longitudinal study of behavioral, emotional and social difficulties in individuals with a history of specific language impairment (SLI). J Commun Disord, 2011; 44: 186-99.

24. McCabe P.C, Meller P. The relationship between language and social competence: How language impairment affects social growth. Psychol Sch, 2004; 41: 313-21.

25. Fujiki M, Brinton B. Social skills of children with Specific Language Impairment. Lang Speech Hear Serv Sch, 1996; 27: 195-202.

26. Ullman MT, Pierpont EI. Specific language impairment is not specific to language: The procedural deficit hypothesis. Cortex, 2005; 41(3): 399-433. 